\title{
Epizootiology of Sphaerospora truttae (Myxozoa: Myxosporea) infections of Atlantic salmon Salmo salar at freshwater smolt producing hatcheries in Scotland
}

\author{
J. McGeorge* ${ }^{*}$ C. Sommerville, R. Wootten \\ Institute of Aquaculture, University of Stirling, Stirling FK9 4LA, United Kingdom
}

\begin{abstract}
Juvenile Atlantic salmon Salmo salar L. at a number of Scottish smolt units become infected each year by the myxosporean parasite Sphaerospora truttae. The first detectable signs of infection occurred in late June/early July in fish in their first year on site, when extrasporogonic stages were found in the blood and kidney interstitium. These stages proliferated in the fish until early September. Sporogonic stages occurred in the kidney tubules from early August, with mature spores first present in September. The prevalence and intensity of each of these developmental stages was recorded over a $3 \mathrm{yr}$ period at 2 hatcheries. Marked temperature differences existed between the 2 farms which appeared to be responsible for differences in the intensity of the parasite at each location. Temperature also appeared to be important in the short term synchronous release of the infective stage of the parasite. A pre-patent period of 2 to $4 \mathrm{wk}$ was identified between the point at which fish became infected and when infections became detectable. Mature spores remained in fish held away from sources of reinfection for at least 18 mo but, on transfer to sea, spores were lost within $4 \mathrm{mo}$. A comparative study of fish aged $1+$ which had been exposed to infection in their first year with those which were naive indicated that previously exposed fish were subsequently refractory to reinfection, but that susceptibility was not age dependent.
\end{abstract}

KEY WORDS: Sphaerospora $\cdot$ Epizootiology $\cdot$ Atlantic salmon $\cdot$ Extrasporogonic stages $\cdot$ Reinfection studies

\section{INTRODUCTION}

There are few sequential studies of the epizootiology and seasonal dynamics of myxosporean infections (Brummer-Korvenkontio et al. 1991). Of these, the more detailed reports have described the epizootiology of economically important species infecting fish held under intensive culture conditions (Wyatt 1978 , Ching \& Munday 1983, Amandi et al. 1985, Foott \& Hedrick 1987). It appears from such work that in temperate areas, especially in the freshwater environment, temperature is often a major factor influencing myxosporean infections, with seasonal epizootics common (Mitchell 1977, Lom \& Dyková 1992). Cultured fish

•E-mail: jm4@stir.ac.uk represent ideal populations for study since they provide a cohort which can be easily followed from hatching and regularly sampled over a prolonged period.

Myxosporean species of the genus Sphaerospora are of particular interest, since a number of species are significant pathogens. Detailed reports of the epizootiology of Sphaerospora spp. exist for $S$. renicola (Grupcheva et al. 1985, Odening et al. 1988a, Sedlaczek et al. 1990) and 2 species parasitic in Mediterranean sea bass Dicentrarchus labrax L.: S. testicularis and S. dicentrarchi (Sitja-Bobadilla \& Alvarez-Pellitero 1993). Data also exists on the epizootiology of the PKX myxosporean, the causative agent of proliferative kidney disease of salmonids, PKD (Ellis et al. 1985, Foott \& Hedrick 1987, Odening et al. 1988b). A number of studies have postulated that this organism may be a 
member of the genus Sphaerospora (Hedrick et al. 1988, Kent et al. 1993).

The present paper reports the findings of a 3 yr programme of epizootiological and experimental studies carried out at a number of Scottish fish farms producing Atlantic salmon Salmo salar L. smolts. Fish at these sites become infected each year with Sphaerospora. The parasite, especially its extrasporogonic stage, is considered to be a significant pathogen by farmers and causes histopathological changes in the kidney ( $\mathrm{J}$. McGeorge, C. Sommerville \& R. Wootten unpubl.). The morphology and ultrastructure of the development of this myxosporean were presented by McGeorge et al. (1994). The parasite has two distinct life cycle phases within the salmon host, an extrasporogonic stage in the blood and kidney interstitium which appears to be proliferative, and a sporogonic stage in the lumen of the kidney tubules which produces mature spores in disporous pseudoplasmodia. McGeorge et al. (1994) considered that the salmon Sphaerospora sp. was probably S. truttae (Fischer-Scherl et al. 1986), but cautioned against a definite identification. However, recent experimental studies have confirmed that the salmon parasite is S. truttae (McGeorge et al. 1996).

\section{MATERIALS AND METHODS}

Seasonal dynamics. Sampling programme: Two hatcheries producing Atlantic salmon smolts, farm A and farm B, were sampled from January 1991 to July 1993. Farm A lies on the west coast of Scotland and produces only $S_{1 / 2}$ smolts (i.e. 6 mo old) for transfer to sea in the autumn of their first year. Farm B is situated in the north of Scotland and, although mainly producing $\mathrm{S}_{1}$ Atlantic salmon smolts for spring transfer, also rears some $S_{1 / 2}$ fish. Routine samples of 25 fish were taken on average every $3 \mathrm{wk}$ from the single year class of fish present on site, from their hatching through to their transfer to sea as smolts. The same tank was followed, when possible, throughout this period at each farm.

Fish from each sample were sacrificed within $24 \mathrm{~h}$ of return to the laboratory and examined by standardised procedure for the detection of myxosporean parasites (see McGeorge et al. 1994).

Prevalence and intensity: Prevalence was calculated as the percentage of the total number of fish examined at a sampling date found to be infected with either (1) extrasporogonic, and/or (2) sporogonic stages of Sphaerospora truttae.

Intensity of infection in each fish within the sample was calculated for extrasporogonic and sporogonic stages in a semi-quantitative manner. Intensity of extrasporogonic stages was scored from Giemsa
Table 1. Scoring system for intensity of extrasporogonic stage

\begin{tabular}{|cl|}
\hline Intensity index & Extrasporogonic stages \\
\hline $1+$ & Detectable infection \\
$2+$ & 1 or less parasites per field \\
$3+$ & $1-2$ parasites per field \\
$4+$ & $2-3$ parasites per field \\
$5+$ & More than 3 parasites per field \\
\hline
\end{tabular}

stained impression smears of the whole kidney. A scale of $1+$ to $5+$ was devised according to the mean number of extrasporogonic stages per field from 40 viewing fields at $\times 250$ magnification (Table 1 ). Category $1+$ refers to slides where 40 fields yielded no parasites, but more detailed scanning of the entire slide showed the parasite to be present.

Giemsa stained impression smears and histological slides were found to be unrepresentative of the number of sporogonic stages that were seen in fresh kidney squash preparations. Intensity levels of sporogonic stages were therefore determined from fresh preparations. However, intensity of infection was not simply related to the number of tubules infected, but also to the number of sporogonic stages in each infected tubule. Kidneys were therefore scored in terms of the proportion of total tubules from 40 random fields which contained sporogonic stages expressed on a scale of 1 to 10 (10 being all tubules infected). This figure was then multiplied by an intensity factor of 1 to 5 , to reflect the average number of sporogonic stages within each infected tubule. The resulting figure, ranging from 1 to 50 , was scaled down by a factor of 10 and rounded to the nearest whole number to give an intensity index of $1+$ to $5+$ comparable with that for extrasporogonic stages.

Mean intensity for a sample of fish from 1 sampling occasion was calculated as the sum of individual intensity indices divided by the number of infected fish in the sample. The degree of variation within a single sample was expressed by the range of intensity indices shown by the 25 fish within a single sample.

Experimental studies. Exposure of fish to Sphaerospora truttae infection: The relevant cohort of fish for each experiment was infected by exposing the fish in clean glass-fibre tanks at farms supplied with river water known to harbour the infective agent for $S$. truttae.

Date of first infection and pre-patent period: For this experiment, farm A was used to establish when fish first became infected with Sphaerospora truttae, and to compare this date with the first detectable signs of infection in routine samples. Sampling for the experiment began in late April 1992, and was carried out coincidentally with the routine epidemiological sam- 
pling programme as follows: in addition to the routine sample of 25 fish, a further 10 fish were obtained on each sampling date. Each group of 10 extra fish was retained separately in pathogen free water in the laboratory. When extrasporogonic stages were first detected by the examination of routine samples, retained fish from all previous sampling dates were examined to determine whether they were infected.

Period for which spores were present: This experiment was designed to determine how long mature Sphaerospora truttae spores remained in infected fish following the disappearance of extrasporogonic stages. Sampling at a third farm, farm $C$, established that salmon had been infected by extrasporogonic stages of S. truttae in their first summer (1991), and had contained mature spores by October that year at a prevalence rate of $100 \%$. Thirty of these fish were sampled in May 1992, prior to transfer to sea, and retained in pathogen free freshwater in the laboratory. Two fish were examined from this population each month until May 1993 and examined for the presence of extrasporogonic and sporogonic stages of $S$. truttae.

Effect on sporogonic stages of transfer to sea water: The final freshwater sample of fish from farm $\mathrm{A}$ in November 1991 was found to be infected with sporogonic stages of Sphaerospora truttae at a prevalence of $90 \%$. Following their transfer to marine rearing facilities in the same month (as $\mathrm{S}_{1 / 2}$ smolts), 10 fish from this cohort were sampled and examined at 4, 8, and $16 \mathrm{wk}$ to determine the effects of sea transfer on spores and sporogonic stages.

Sphaerospora infections of Atlantic salmon in their second year: Three groups of fish were utilised to establish if fish previously exposed to Sphaerospora truttae could be reinfected and/or if fish age had an effect on whether infection occurred.

Group 1, a reinfection group, were the 1991 cohort of potential $\mathrm{S}_{2}$ Atlantic salmon of age $1+$, from farm $C_{\text {; }}$ these fish were infected with Sphaerospora truttae at a $100 \%$ prevalence, and high intensity during their first summer on site (August 1991). Two samples were taken from this group during the summer of 1992, their second summer exposed to infective waters on site (mid-July, 15 fish; mid-August, 12 fish) and examined to determine whether a second natural exposure to the infective agent for $S$. truttae led to the establishment of new infection.

Group 2, a control group for group 1, consisted of $0+$ Atlantic salmon parr of the 1992 cohort of farm $C$, in their first summer on site, i.e. being exposed to infective waters for the first time. Ten of these fish were sampled on the same dates in July and August 1992 as the fish of group 1, and examined in order to confirm that all fish on site were being exposed to infective stages of Sphaerospora truttae during the summer of
1992. A third group of fish, group 3, consisted of potential $\mathrm{S}_{2}$ Atlantic salmon of age $1+$ with no history of $S$. truttae infection, since they had spent their first year on a specific pathogen free water supply. These were chosen to ensure that any differences seen between groups 1 and 2 were not simply due to an age effect (such as increased immunocompetence) between $0+$ and 1+ fish. Unfortunately, for husbandry reasons these fish could not be exposed at farm $C$. They were therefore exposed at farm $D$, on the northwest coast of Scotland, a growing-on site known to be $S$. truttaeinfected. Six fish were examined from this site in July 1993, their second summer, but their first at a site infective for $S$. truttae, to determine whether fish not previously exposed to infection could become infected in their second year.

\section{RESULTS}

\section{Seasonal dynamics}

The prevalence rate and mean intensity of infection of both extrasporogonic and sporogonic stages of Sphaerospora over time, for the 1991 and 1992 year classes of salmon at farms A and B, are given in Figs. 1 to 4. Hatchery temperature data for both farms is shown in Fig. 5.

Extrasporogonic stages - prevalence. At both farms $A$ and $B$ it was clear that extrasporogonic stages occurred for only a restricted period each year (Figs. 1 $\& 2)$. Although fish at both sites were transferred into river water in February/March each year, extrasporogonic stages were not evident until late June to midJuly each year at both farms. Actual sample dates for first detected infections are given in Table 2 ; the date of the previous, negative sample is provided in each instance. If these are taken into account, first infections could have been present in mid- to late June.

The prevalence rate of extrasporogonic stages rose very rapidly from first detection, peaking each year in July and August. At farm A, peak prevalence reached $80 \%$ and $100 \%$ in late July 1991 and early August 1992 respectively. At farm B, prevalences were lower, especially in 1991, where prevalence peaked at only 40\% in late July. In 1992 peak prevalence was 65\% in mid-July.

Extrasporogonic stages were last detected in midSeptember at farm A in both 1991 and 1992, but at farm $B$ the latest sample in which they were found was that of mid- to late August (Table 2). Extrasporogonic stages were thus detectable in regular samples for around 8 to 12 wk at farm $A$ in the $91 / 92$ year class and both farms in the $92 / 93$ year class, but only 3 to $4 \mathrm{wk}$ in the $91 / 92$ year class at farm B. 

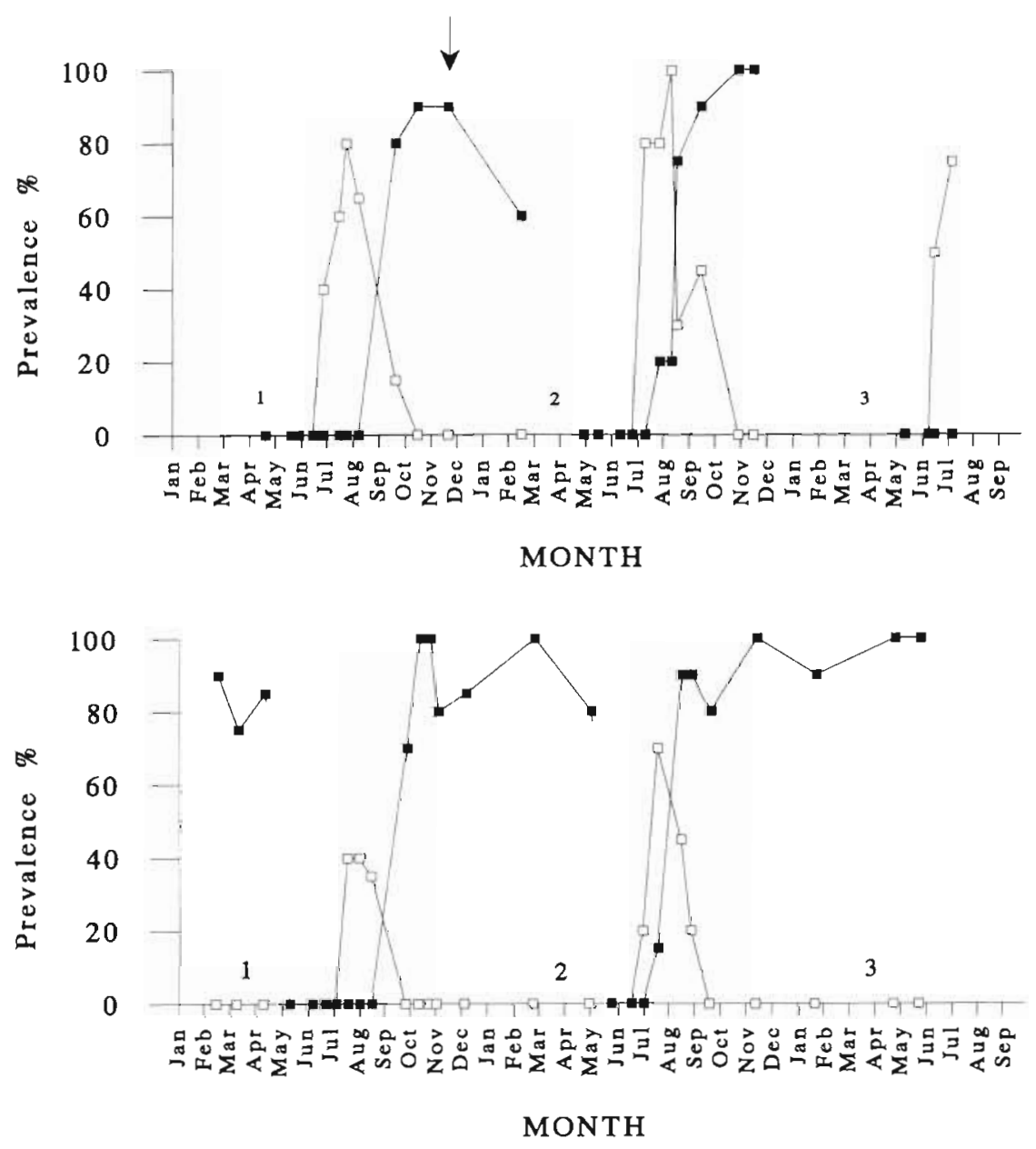

Fig. 1. Salmo salar. Prevalence of extrasporogonic (回) and sporogonic ( stages of Sphaerospora truttae from 3 separate year classes of Atlantic salmon at Farm A; (1) 1991; (2) 1992; (3) 1993. The drop in prevalence of sporogonic stages seen in February 1992 for the 1991 year class follows their transfer to sea in November 1991 (arrow)
Extrasporogonic stages-intensity. Peak mean intensities of infection and the greatest range of intensity in single samples at both farms and in both years occurred in July and August, mirroring the peak prevalence rate within the population.

Mean intensity at farm A peaked at around 3+ or 4+ in both cohorts studied, whereas at farm $B$, this figure was between $1+$ and $2+$ each year (Figs. 3 \& 4). In terms of intensity range within each sample, the differ-

Table 2. Salmo salar. Time for which extrasporogonic stages were present in 1991 and 1992 cohorts of Atlantic salmon at farms $A$ and $B$. Dates of the negative sample prior to the first positive sample are given, along with those of the first negative sample following the last positive sample

\begin{tabular}{|cccccc|}
\hline Farm Cohort & Previous \\
negative & $\begin{array}{c}\text { First } \\
\text { detection }\end{array}$ & $\begin{array}{c}\text { Last } \\
\text { detection }\end{array}$ & $\begin{array}{c}\text { First } \\
\text { negative }\end{array}$ \\
\hline A & 1991 & 15 Jun'91 & 27 Jun'91 & 19 Sep'91 & 15 Oct'91 \\
A & 1992 & 17 Jun'92 & 09 Jul'92 & 13 Sep'92 & 27 Sep'92 \\
B & 1991 & 04 Jul '91 & 18 Jul'91 & 15 Aug'91 & 25 Sep'91 \\
B & 1992 & 16 Jun'92 & 30 Jun'92 & 26 Aug'92 & 20 Sep'92 \\
\hline
\end{tabular}

ences between the 2 farm sites were even more notable; at farm $A$, some fish carried the highest intensity levels $(5+)$ in both years, whereas at farm $B$ the most heavily infected fish attained an intensity of only $2+$ or $3+$. At both farms, even when the prevalence of infection in the population was as high as $100 \%$, and mean intensity was high, range data indicated that some infected fish still harboured very low level infections $(1+)$ on almost all sampling dates.

Sporogonic stages-prevalence. In the 1991 year classes at both farms, sporogonic stages were only recorded in terms of the presence of mature spores whereas in samples from the 1992 cohort of fish, presporogonic pseudoplasmodia as well as mature spores were included. Sporogonic stages rapidly rose in prevalence from first detection, to reach a maximum prevalence of above $90 \%$ in August or September for each of the 2 year classes at both farms (Figs. 1 \& 2). Prevalence of sporogonic stages in routine samples then remained at or around this level until the fish were transferred to sea, in October/

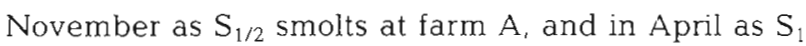
smolts at farm $B$. 
Fig. 3. Salmo salar. Mean intensity and range data for extrasporogonic ( $\square$ ) and sporogonic (ש) stages of Sphaerospora truttae from 2 separate year classes of Atlantic salmon at farm $A_{i}$ (1) 1991; (2) 1992

Fig. 4. Salmo salar. Mean intensity and range data for extrasporogonic (ㅁ) and sporogonic (ロ) stages of Sphaerospora truttae from 2 separate year classes of Atlantic salmon at farm $B_{i}$ (1) 1991; (2) 1992

Fig. 5. Mean weekly hatchery temperatures compared for farm A (dotted line) and farm B (solid line). Although highest water temperatures are similar, note the longer period for which temperature exceeds $11^{\circ} \mathrm{C}$ at farm A each year. Note also the rapid rise in temperature at both farms, particularly farm B, in May/June which may stimulate release of the infective stage of the parasite from the wild source of infection, and the rapid drop in late August each year, which may be the stimulus for the transition from extrasporogonic cycling to sporogony
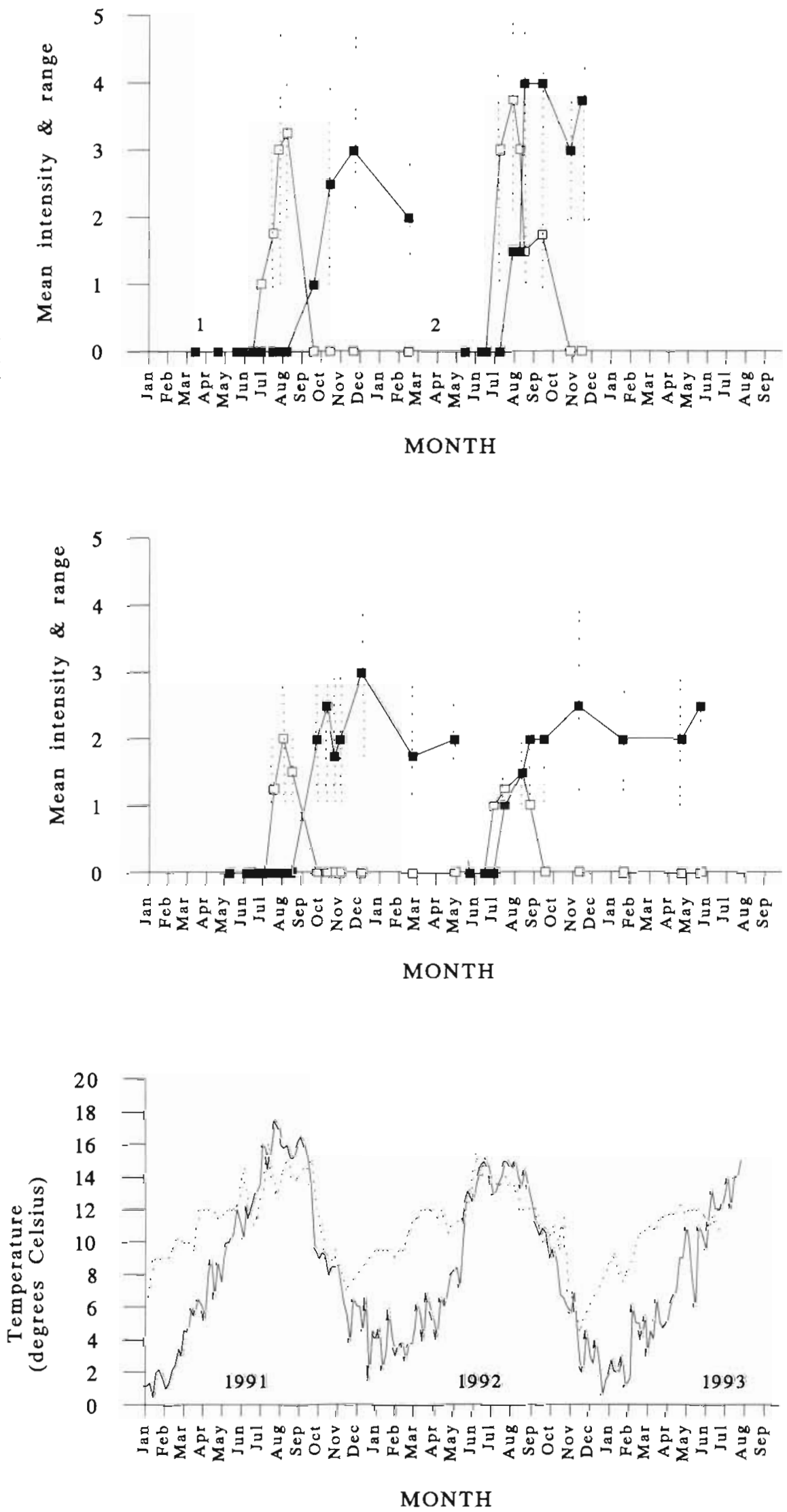
Sporogonic stages-intensity. Mean intensity values for sporogonic stages at both farms reached maximum levels in September or October each year, after which there appeared little or no further change in intensity until fish were transferred to sea cages (Figs. 3 \& 4). At farm A mean intensity levels and their range at a given sampling point were invariably higher than those at farm B. Again, as with extrasporogonic stages it was clear that even when prevalence and mean intensity were high within the cohort, some individuals carried relatively low level infections of $1+$ or $2+$.

\section{Experimental studies}

Date of first infection and pre-patent period. The experiment to determine the date of first infection and pre-patent period, carried out in 1992, compared the first appearance of extrasporogonic stages in routine samples with fish retained from earlier sampling dates and maintained thereafter on pathogen free water. Although the first positive sample in 1992 from farm A was that taken on 9 July 1992, the retained sample immediately prior to that which produced the first positive, that of 24 June 1992, was found to be infected at a prevalence of $80 \%$ ( 8 out of 10 fish) when examined. Fish from all other previous samples were uninfected. Therefore there appeared to be a period of some 2 to 4 wk between when fish became infected and when that infection reached a detectable level or became detectable with the techniques used.

Period for which spores were present. The fish from the 1991 cohort at farm C, held on infection free waters from May 1992 onwards, were found to retain spores until May 1993 when they were last examined. The prevalence within these fish remained at $100 \%$ throughout this time, during which the intensity of infection appeared to be constant, evaluated on a subjective basis.

Effect on sporogonic stages of transfer to sea water. Four weeks after their transfer to sea water in November 1991, the cohort at farm $\mathrm{A}$, being studied to determine the effects of host transfer to sea, retained a $100 \%$ prevalence rate of sporogonic stages (10/10 fish) and no apparent changes were seen in spore and prespore stage structure. However, after 2 mo at sea, in early February 1992, the prevalence had declined to $60 \%(6 / 10 \mathrm{fish})$, and the mean intensity of infection and its range had also dropped markedly from $3+(2+$ to $5+)$ to $2+(1+$ to $3+)$. Fresh smear and histological observations indicated that only mature spores remained in infected tubules, differentiating pseudoplasmodia being absent. These spores appeared particularly 'compact' and were no longer retained within pseudoplasmodia attached to the inner wall of the tubule, but were loose in the tubular lumen. In April 1992, after 4 mo in sea water, sporogonic stages and mature spores were absent ( $0 / 7$ fish).

Sphaerospora infections of salmon in their second year. The study of $S$. truttae infections of salmon in their second year found that the fish of group 1 , the 1991 cohort at farm C, which had suffered 100\% prevalence of infection by extrasporogonic stages in summer 1991, were not infected with extrasporogonic stages during July (0/15 fish) and August (0/12 fish) 1992. These fish did contain large numbers of mature spores on both dates but these were considered to result from their infection as $0+$ fish in summer 1991. Group 2, the previously unexposed 0+ 1992 cohort of salmon in their first year on the same water supply as group 1, were infected at $100 \%$ prevalence by extrasporogonic stages on both sampling dates.

Group 3, naive 1+ fish exposed at farm D, were successfully infected at age $1+i n$ the summer of 1993 with extrasporogonic stages (5 of 6 fish). One fish was infected at very high intensity $(5+)$, the other 4 at a mean of 2.25 (range $1+$ to $4+$ ).

\section{DISCUSSION}

\section{Prevalence and intensity data}

Although the mean intensity differed between farms $A$ and B, the prevalence of Sphaerospora truttae sporogonic stages reached $100 \%$ each year at both. However, the prevalence for extrasporogonic stages often peaked at a lower figure; in only 1 instance (1992, farm A) did the extrasporogonic stage prevalence reach a level of $100 \%$, whilst at farm B, especially in the 1991 cohort, extrasporogonic stage prevalence was much lower. Of course, all of these fish must have harboured extrasporogonic stages at some point, since they all subsequently contained sporogonic stages. This might in part be explained by the difficulties of detecting low intensity levels of myxosporean infection, such as those found at farm $B$. This is illustrated by the presence of a pre-patent period when the parasite cannot be detected in the present study and has also been more generally acknowledged (Mitchell 1977, Lom \& Dyková 1992). Another factor may be that extrasporogonic stages peak in prevalence rapidly and over a short period of time in the host population.

In most Sphaerospora spp in which extrasporogonic stages have been demonstrated they precede the appearance of sporogonic stages, are only present for a short period of time and do not persist following sporogony (Foott \& Hedrick 1987, Hedrick et al. 1988, 1990, Sedlaczek et al. 1990). This pattern is also shown by $S$. truttae. However, the C-blood stages of 
$S$. renicola may be present for long periods after sporogony has been completed (Grupcheva et al. 1985, Molnár 1988, Odening et al. 1988a). Odening et al. (1988a) reported 2 types of seasonal variation in $S$. renicola, and suggested that seasonal changes in prevalence of both extrasporogonic and sporogonic stages may be due to internal rhythms inherent in the parasites themselves rather than because of declining infection or reinfection.

The rapid rise in prevalence of sporogonic stages within the fish cohorts might indicate that some stimulus causes extrasporogonic stages to become sporogonic synchronously, or alternatively that some endogenous parasite rhythm is responsible. The window for which extrasporogonic stages are present seems to correlate closely with the time for which temperatures remain above 11 to $12^{\circ} \mathrm{C}$ (Fig. 5), so it could be that a fall below $12^{\circ} \mathrm{C}$ at this time is responsible.

Prevalence and intensity of sporogonic stages remained at very similar levels at both farms from late September, when mature spores were first found, until the fish were put to sea. As there are no extrasporogonic stages in the fish from September onwards, no additional early sporogonic forms are being produced by extrasporogonic stages to establish in the kidney tubules to maintain this constancy. Although there is no evidence from this study, it could be that a further, presporogonic, rather than extrasporogonic, proliferative process may occur involving existing sporogonic stages present in the kidney tubules. The possibilty that a hitherto unknown reservoir phase may exist has been suggested for Sphaerospora renicola (Odening et al. 1988a). Alternatively, perhaps spores are simply not released, or released only very slowly within the period of time that $S_{1 / 2}$ or $S_{1}$ cultured fish spend in freshwater. Certainly, the retained $\mathrm{S}_{2}$ fish from farm $\mathrm{C}$, held in non infective waters from late summer 1992, still contained mature spores and pre-sporogonic stages in summer 1993. Spores must have been initially formed in these fish in autumn 1991, i.e. 20 mo previously. FischerScherl (pers. comm. 1992) found that brown trout isolated from any possible source of reinfection maintained spores of $S$. truttae for at least $3 \mathrm{yr}$, whilst Grupcheva et al. (1985) found that sporogonic stages remained in carp infected with $S$. renicola for $3 \mathrm{yr}$. In rainbow trout harbouring both PKX and Sphaerospora sp. spores in Germany, Odening et al. (1988b) reported low levels of spore release on an irregular and intermittent basis from November of their first year of infection.

\section{Timing of development}

The present study demonstrated that a pre-patent period of 15 to $28 \mathrm{~d}$ existed between the point at which salmon became infected with Sphaerospora truttae and the point at which infections became detectable in the population. Periods of $40 \mathrm{~d}$ and $25 \mathrm{~d}$ have been recorded for Myxobolus cerebralis and PKX respectively (Clifton-Hadley \& Feist 1989, ElMatbouli et al. 1992). It could be that during this period the parasite is present at such a low intensity that its detection is not possible using the techniques employed, or that it has a developmental stage in another location in the fish, such as that recently demonstrated for the earliest stages of $M$. cerebralis in the central nervous system, skin and gills of rainbow trout (El-Matbouli et al. 1995).

If we include the pre-patent period, extrasporogonic stages of Sphaerospora truttae are present from midMay to late September (16 to $18 \mathrm{wk}$ ) at maximum. Sporogonic stages first appeared 17 to 31 d later, followed by the first mature spores at 48 to $80 \mathrm{~d}$. Foott \& Hedrick (1987) found the first sporogonic stages of PKX around $30 \mathrm{~d}$ after the appearance of extrasporogonic stages in a study carried out in the USA, whilst in a study in the UK, Clifton-Hadley \& Feist (1989) found first sporogonic stages of PKX at $63 \mathrm{~d}$ with first 'spores' after $98 \mathrm{~d}$. Odening et al. (1988b) however found no seasonal patterns for PKX and Sphaerospora sp. spores in studies of infection in rainbow trout.

Extrasporogonic stages first became detectable in each fish cohort between the end of June and midJuly each year. Allowing for the pre-patent period, infections at all farms could not occur until May at the very earliest, despite the fish having been exposed to river water since January/February. The fact that the prevalence of extrasporogonic stages rose rapidly thereafter in all cohorts suggests that all fish within the year class became infected at a similar time. Such initial synchronous waves of infection have been shown similarly for Ceratomyxa shasta (Ching \& Munday 1983), Myxobolus cerebralis (Shulman 1966) and PKX (Foott \& Hedrick 1987), and must be reflective of a synchronous release of (presumably) mature actinosporean spores from oligochaete alternate hosts, stimulated by a suitable environmental or endogenous trigger in or around May. One possible stimulus could be a rise in temperature. Each year, the first signs of infection appear closely related to the point when water temperatures rise above $\sim 11^{\circ} \mathrm{C}$ at both farms, particularly farm B.

\section{Differences between farms}

The mean intensity of infection with Sphaerospora truttae and its range within the population at any time was much higher at farm $A$ than at farm B. A positive correlation between actinosporean dose and infection 
level has been demonstrated for Myxobolus cerebralis (Markiw 1986) and, in terms of exposure time to infective waters, for Myxobolus pavlovskii (Molnár 1979bj. Differences in mean intensity may therefore reflect a difference in the numbers of infective stages of the parasite entering the farm and reaching the fish. These could result from differences in abundance or ecology and infection level of either host in the wild, or management factors within the farm, which in turn may influence the immunocompetence of the fish and their ability to resist infection. Farm B mixes river water with water from a small stream with very few wild fish, which may also mitigate against high infections. Stocked fish strain may affect susceptibility to infection, since the 2 farms stock salmon from different egg producers. There is much evidence of stock strain variations in susceptibility to myxosporean infection within single host species, especially amongst salmonids infected with Ceratomyxa shasta (Zinn et al. 1977, Johnson et al. 1979, Hemmingsen et al. 1986) and PKX (Ellis et al. 1985). Perhaps local differences in environmental conditions at each farm could be responsible. A lower average water temperature might cause a shorter release of infective stages, for example, leading to a shorter window in which extrasporogonic stages are present. At farm A, water temperatures at or above 11 to $12^{\circ} \mathrm{C}$ occurred for around 6 mo in the summers of both 1991 and 1992, whilst at farm B equivalent temperatures were attained for only 3 to 3.5 mo (Fig. 5). Lower temperatures might also mean that at farm $B$ extrasporogonic cycles continue for a shorter period than at farm $A$ and thus lower intensities of infection are established.

It might be assumed that any fish infected by Sphaerospora truttae would go on to attain a high intensity of infection due to the proliferative cycling of extrasporogonic stages, but this is not the case. In some other species of Sphaerospora (Molnár 1979a) fish are either uninfected or infected at very high levels, which can be attributed to the presence of an effective extrasporogonic proliferation. But even when the mean intensity of infection was high, many salmon in the present study carried low level infections. The proliferative nature of the extrasporogonic stages must therefore in some way be mediated by other factors. Perhaps extrasporogonic primary cells can undergo only a finite number of cycles prior to all released cells becoming sporogonic. Alternatively, perhaps such stages cycle for a limited period of time in the fish or between certain temperature limits, until a temperature or other cue initiates sporogony. Whatever the cause, the length of time for which extrasporogonic stages are present in the population each year is limited.

\section{Sea water effects}

Spores and sporogonic stages were completely lost from the kidney tubules of salmon in sea water within 4 mo. No fish were subsequently brought back onto freshwater to see whether sporogony could recommence as it does in Myxidium salvelini (Higgins et al. 1993). Although this cannot be ruled out, it seems unlikely, since in $M$. salvelini pre-sporogonic plasmodial stages remained dormant in the kidney tubules and later resumed their development on return of the host to freshwater. In Sphaerospora truttae these stages were the first to be lost in sea water. There are no records of Sphaerospora sp. in the kidneys of adult Atlantic salmon returning from sea water, although $S$. oncorhynchi spores can be found in adult Pacific salmon returning to freshwater (Kent et al. 1993).

\section{Reinfection studies}

Salmon previously exposed to Sphaerospora truttae appear to be refractory to future reinfection. They do, however retain mature and developing spores resulting from their initial infection the previous summer. This is very similar to the situation seen in fish which recover from PKX infection (Ferguson \& Ball 1979, Foott \& Hedrick 1987) and whirling disease caused by Myxobolus cerebralis (Hoffmann et al. 1992).

That resistance to Sphaerospora truttae was acquired as a result of exposure to infection, rather than simply due to factors associated with increasing fish age and size was shown by the group 3 fish from farm D, not previously exposed to Sphaerospora, which suffered high levels of infection with extrasporogonic stages at age $1+$ in the summer of 1993 when moved to an infected site. Odening et al. (1989) showed similarly that previously naive 1 yr old carp were susceptible to $S$. renicola. The mechanisms of resistance to myxosporean infections merit further study, especially when one considers the pathogenicity of many such infections.

It would seem reasonable to propose that in epizootiological terms Sphaerospora truttae has evolved a life cycle in the same manner as that of Myxobolus cerebralis and $\mathrm{PKX}$, that is timed to result in the maximal infection of $0+$ fish in the summer of each year, i.e. a time at which naive hosts are at their most abundant in the environment.

Acknowledgements. The authors thank Maureen Menzies for her technical help, and the farms concerned for their co-operation during the period of the study. This work was funded by an N.E.R.C. research studentship. 


\section{LITERATURE CITED}

Amandi A, Holt RA, Fryer JL (1985) Observations on Myxobolus insidiosus (Myxozod: Myxosporea) a parasite of salmonid fishes. Fish Pathol 20:187-304

Brummer-Korvenkontio $H$, Tellervo-Valtonen E, Pugachev ON (1991) Myxosporean parasites in roach, Rutilus rutilus (Linnaeus), from four lakes in central Finland. J Fish Biol 38:573-586

Ching HL, Munday DR (1983) Geographic and seasonal distribution of the infectious stage of Ceratomyxa shasta Noble, 1950, a myxozoan salmonid pathogen in the Fraser river system. Can J Zool 62:1075-1080

Clifton-Hadley RS, Feist SW (1989) Proliferative kidney disease in brown trout Salmo trutta: further evidence of a myxosporean aetiology. Dis Aquat Org 6:99-103

Ellis AE, McVicar AH, Munro ALS (1985) Proliferative kidney disease in brown trout, Salmo trutta L., and Atlantic salmon, Salmo salar L., parr: histopathological and epidemiological observations. J Fish Dis 8:197-208

El-Matbouli M, Hoffmann RW, Fischer-Scherl $\Upsilon$ (1992) Present knowledge on life cycle and mode of transmission of myxosporeans. International workshop on myxosporeans. October 6-8, 1992, Ceské Budějovice, Czechoslovakia. (Abstract)

El-Matbouli M, Hoffmann RW, Mandok C (1995) Light and electron microscopic observations on the route of the triactinomyxon-sporoplasm of Myxobolus cerebralis from epidermis into rainbow trout cartilage. J Fish Biol 46: 919-935

Ferguson HW, Ball HJ (1979) Epidemiological aspects of proliferative kidney disease amongst rainbow trout Salmo gairdneri Richardson in Northern Ireland. J Fish Dis 2: $219-225$

Fischer-Scherl T, El-Matbouli M, Hoffmann RW (1986) A new Sphaerospora sp. in brown trout (Salmo trutta $m$. fario) in Germany. Bull Eur Ass Fish Path 6:16-19

Foott JS, Hedrick RP (1987) Seasonal occurrence of the infectious stage of proliferative kidney disease (PKD) and resistance of rainbow trout, Salmo gairdneri Richardson, to reinfection. J Fish Biol 30:477-484

Grupcheva G, Dyková I, Lom J (1985) Seasonal fluctuation in the prevalence of Sphaerospora renicola and myxosporean bloodstream stages in carp fingerlings in Bulgaria. Fol Parasitol 32:193-203

Hedrick RP, Kent ML, Toth RJ, Morrison JK (1988) Fish infected with Sphaerospora spp. Thelohan (Myxosporea) from waters enzootic for proliferative kidney disease of salmonids. J Protozool 35:13-18

Hedrick RP, McDowell T, Groff JM (1990) Sphaerospora ictalurin. sp. (Myxosporea: Sphaerosporidae) observed in the kidney of channel catfish, Ictalurus punctatus Rafinesque. J Protozool 37:107-112

Hemmingsen AR, Holt RA, Ewing RD, McIntyre JD (1986) Susceptibility of progeny from crosses among three stocks of coho salmon to infection by Ceratomyxa shasta. Trans Am Fish Soc 115:492-495

Higgins MJ, Margolis L, Kent ML (1993) Arrested development in a freshwater myxosporean Myxidium salvelini, following transfer of its host, the sockeye salmon $(\mathrm{On}$ corhynchus nerka), to sea water. J Parasitol 79:403-407

Hoffmann RW, El-Matbouli M, Hoffmann-Fezer G (1992) Immunoreactions against the agent of whirling disease in rainbow trout (Oncorhynchus mykiss). International workshop on myxosporeans. October 6-8, 1992, Ceské Budějovice, Czechoslovakia. (Abstract)
Johnson KA, Sanders JE, Fryer JL (1979) Ceratomyxa shasta in salmonids. Fish Disease Leaflet 58. US Department of the Interior, Fish and Wildlife Service, Washington, DC

Kent ML, Whitaker DJ, Margolis L (1993) Sphaerospora oncorhynchi n. sp. (Myxosporea: Sphaerosporidae) from the kidney of sockeye salmon (Oncorhynchus nerka) in British Columbia and its possible relationship to the myxosporean causing proliferative kidney disease in salmonid fishes. Can J Zool 71:2425-2430

Lom J, Dyková I (1992) Myxosporidia (Phylum Myxozoa). In: Lom J, Dykova I. Protozoan parasites of fishes. Developments in aquaculture and fisheries science, Vol 26. Elsevier Science Publications, Amsterdam

Markiw ME (1986) Salmonid whirling disease: dynamics of the experimental production of the infective stage - the triactinomyxon spore. Can J Fish Aquat Sci 43:521-526

McGeorge J, Sommerville C, Wootten R (1994) Light and electron microscope observations on extrasporogonic and sporogonic stages of a myxosporean parasite of the genus Sphaerospora Thélohan, 1892 from Atlantic salmon, Salmo salar L., in Scotland. J Fish Dis 17:227-238

McGeorge J, Sommerville C, Wootten R (1996) Transmission experiments to determine the relationship between Sphaerospora sp. from Atlantic salmon, Salmo salar, and Sphaerospora truttae: a revised species description for $S$. truttae. Fol Parasitol 43:107-116

Mitchell LG (1977) Myxosporidia. In: Kreier JP (ed) Parasitic Protozoa, Vol 4. Academic Press, New York

Molnár K (1979a) Gill sphaerosporosis in the common carp and grasscarp. Acta Vet Hung 27:99-113

Molnár K. (1979b) Myxobolus pavlovskii (Achmerov, 1954) (Myxosporidia) infection in the silver carp and bighead. Acta Vet Hun 27:207-216

Molnár K (1988) Further evidence that C-blood protozoa of the common carp are stages of Sphaerospora renicola Dyková et Lom, 1982. Bull Eur Ass Fish Path 8:3-4

Odening K, Walter G, Bockhardt I (1988a) Zur jahreszeitlichen Dynamik von Sphaerospora renicola (Myxosporidia) beim Karpfen (Osteichthyes). Angew Parasitol 29:65-80

Odening K, Walter G, Bockhardt I (1988b) Koinzidentes Auftreten von PKX und Sphaerospora sp. (Myxosporidia) in Beständen von Salmo gairdneri (Osteichthyes). Angew Parasitol 29:137-148

Odening $\mathrm{K}$, Walter G, Bockhardt I (1989) Zum Infektionsgeschehen bei Sphaerospora renicola (Myxosporidia). Angew Parasitol 30:131-140

Sedlaczek J, Friede $H$, Kluss $P$, Vinzelberg R (1990) Zum jahreszeitlichen Auftreten der Schwimmblasenentzündung im Verlauf der renicola-Sphaerosporose bei Karpfen. Angew Parasitol 31:219-229

Shulman SS (1966) Myxosporidia of the fauna of the USSR. Nauka, Moscow (English translation 1990)

Sitja-Bobadilla A, Alvarez-Pellitero P (1993) Population dynamics of Sphaerospora dicentrarchi Sitja-Bobadilla et Alvarez-Pellitero, 1992 and S. testicularis Sitja-Bobadilla et Alvarez-Pellitero, 1990 (Myxosporea: Bivalvulida) infections in wild and cultured Mediterranean sea bass (Dicentrarchus labrax L.). Parasitology 106:39-45

Wyatt EJ (1978) Studies on the epizootiology of Myxobolus insidiosus Wyatt and Pratt (Protozoa: Myxosporida). J Fish Dis $1: 233-240$

Zinn JL, Johnson KA, Sanders JE, Fryer JL (1977) Susceptibility of salmonid species and hatchery strains of chinook salmon (Oncorhynchus tschawytscha) to infections by Ceratomyxa shasta. J Fish Res Bd Can 34:933-936

Manuscript first received: September 19, 1995

Revised version accepted: January 17, 1996 